\title{
Assessing Adult Learner's Numeracy as Related to Gender and Performance in Arithmetic
}

\author{
Adeneye O. A. Awofala ${ }^{1 *}$, Blessing E. Anyikwa ${ }^{2}$ \\ ${ }^{1}$ Department of Science and Technology Education, Faculty of Education, University of Lagos, Nigeria \\ \{aawofala@unilag.edu.ng\} \\ ${ }^{2}$ Department of Adult Education, Faculty of Education, University of Lagos, Nigeria \{ebblessing@yahoo.com\} \\ Received on 29 May 2013; revised on 4 September 2013; accepted on 1 October 2013; published on 15 July 2014 \\ DOI: $10.7821 /$ naer.3.2.83-92
}

\begin{abstract}
The study investigated adult learner numeracy as related to gender and performance in arithmetic among 32 Nigerian adult learners from one government accredited adult literacy centre in Lagos State using the quantitative research method within the blueprint of descriptive survey design. Data collected were analysed using the descriptive statistics of percentages, mean, and standard deviation and inferential statistics of factor analysis, independent samples t-test, and multiple regression analysis. Findings revealed that numeracy skill assessed by the numeracy self-assessment scale was a multi-dimensional construct (numeracy in everyday life, numeracy in workplace, and numeracy in mathematical tasks). Adult learners showed average numeracy strength as gender differences in perception of numeracy skills and performance in arithmetic among adult learners reached zero-tolerance level. Numeracy in workplace and numeracy in mathematical tasks made statistically significant contributions to the variance in adult learners' performance in arithmetic. Based on this base line study, it was thus, recommended that future studies in Nigeria should investigate adult learners' numeracy skills using more robust and psychometrically sound instruments such as the Adult Literacy and Life Skills Survey (ALLS) and the International Adult Literacy Survey (IALS).
\end{abstract}

KEYWORDS: ADULT NUMERACY, GENDER, ADULT EDUCATION, PERFORMANCE IN ARITHMETIC

\section{INTRODUCTION}

The concept of numeracy could be said to have originated from the report for the United Kingdom Ministry of Education (Crowther Report, 1959) and the concept of adult numeracy has gained more popularity in the developed countries such as the United States, Australia, New Zealand and the UK (Cockcroft, 1982; Goyen, 1977; McLennan, 1996; Wickert, 1989). Adult numeracy was initially taken as part of adult literacy (Goyen, 1977) with no visible scale to measure it. Goyen (1977) measured adult literacy with a unidimensional scale and "some

*To whom correspondence should be addressed:

Adeneye O. A. Awofala

University of Lagos, Faculty of Education

Akoka, Yaba

Lagos, Nigeria five years after the British report (Cockcroft, 1982), although told little about adult numeracy, provided a landmark framework to researching and reporting on the mathematical needs of adult life”. The report proposed a definition of numeracy:

We would wish the word 'numerate' to imply the possession of two attributes. The first of these is an 'at-homeness' with numbers and an ability to make use of mathematical skills which enables an individual to cope with the practical mathematical demands of his everyday life. The second is to have some appreciation and understanding of information which is presented in mathematical terms, for instance in graphs, charts or tables or by reference to percentage increase or decrease. (Cockcroft, 1982, p. 11)

Wickert (1989) introduced three literacy dimensions: document literacy, prose literacy, and quantitative literacy. Literacy is defined as using printed information to function in society, to achieve one's goals, and to develop one's knowledge and potential. Document literacy is defined as the ability to use and identify information contained in documents or materials such as tables, schedules, charts, graphs, maps, forms and memos. Prose literacy is the ability to read and interpret prose in newspaper, articles and books while the quantitative literacy is seen as the ability to apply numerical or arithmetic operations to information contained in print materials, such as menus (ABS Aspects of Literacy website; McLennan, 1996; Wickert, 1989). Adult numeracy has been variously used to mean quantitative literacy, quantitative reasoning and statistical literacy (Smit \& Mji, 2012). In addition, a plethora of similar and loosely related terms such as mathematical literacy, techno-mathematical literacy, functional mathematics, and mathemacy compete for attention (Condelli, Safford-Ramus, Sherman, Coben, Gal \& Hector-Mason, 2006) but numeracy in its real sense is more than any one of these concepts.

Quantitative literacy is a subset of numeracy (Johnston, 2002). Although numeracy and literacy are related, they are not the same. Wickert (1989) in his report noted that when people have poor literacy skills, they have even worse numeracy skills and the need to upgrade numeracy skills in the context of literacy must be taken account of in all decisions to raise the levels of adult literacy. Steen (1991) defined numeracy as being “...to mathematics as literacy is to language” (p. 1). A great number of characterisations of numeracy have been postulated in recent times by different authors whose fundamental themes gyrate around numeracy being the understanding and application of 
mathematical principles in order to resolve life's day-to-day challenges (Best, 2008; Evans, 2000; Lindenskov \& Wedege, 2001; Paulos, 1989). Broadly defined, numeracy is taken as mathematical literacy (De Lange, 2003) involving an individual's capacity to identify and understand the role that mathematics plays in the world, to make well-founded judgments, and to engage in mathematics in ways that meet the needs of that individual's current and future life as a constructive, concerned and reflective citizen (OECD, 2000).

Numeracy covers the ability to understand, use, calculate, manipulate, interpret results, and communicate mathematical information. In the adult context, numeracy refers to the practical or functional use of mathematics. According to Ginsburg, Manly \& Schmitt (2006) the term "numeracy” is used in the adult education community to include an array of mathematically related proficiencies that are evident in adults' lives and worthy of attention in adult education settings. They maintained that while there are various definitions of the term numeracy (Coben, 2000; Cockcroft, 1982; Crowther, 1959; Gal, van Groenestijn, Manly, Schmitt \& Tout, 2003; Johnston, 1994; Lindenskov \& Wedege, 2001; and Steen, 2001), all recognise that mathematics and numeracy are related but are not synonymous. Unlike pure mathematics which leads upward in an ascending pursuit of abstraction and is context-free (Ginsburg et al., 2006), numeracy has a distinctive personal life element in which mathematical topics are woven into the context of work and community for richer engagement (Orrill, 2001) in the democratic process (Johnston, 1994) and utility in the competitive global economy (Wedege, 2003). Condelli, et al., (2006) in a study, reviewed the definitions of numeracy using the Maguire \& O’Donoghue's (2002) organizing framework in which numeracy concepts were considered as a continuum of increasing levels of sophistication: formative, mathematical, and integrative. Thus, numeracy is viewed as the basic arithmetic skills (formative phase), situated in context with explicit recognition of importance of mathematics in everyday life (mathematical phase) and gradually incorporating the mathematics, communication, cultural, social, emotional, and personal aspects of each individual in context (integrative phase).

Adult numeracy is an important area of large scale research in many developed countries (Benseman \& Sutton, 2011; EU Skills Panorama, 2012; Johnston, 2002; Lowden, Powney, Gardner \& Mark, 1995; Tett, Hall, Maclachlan, Thorpe, Edwards \& Garside, 2006) including South Africa (Coben, 2000; Smit \& Mji, 2012), but in Nigeria the topic is not yet a corner stone of education research as little or no studies have investigated adult numeracy in general. This is incongruence to the expectations of the Nigerian government at all levels that the society be ridden off innumeracy to the point that an average Nigerian should be able to at least perform basic mathematical computations which are needed in today's $21^{\text {st }}$ century work place.

In general, innumeracy has been found to have both short and long term effects on people's lives (Steen, 1991; Paulos, 1989) including mine workers (Smit \& Mji, 2012) such as inability to control personal finances, inability to make adequate risk assessments, daily activities, and restricted employment opportunities. Without basic numeracy skills, the large numbers of innumerate adult Nigerians cannot be hopeful of securing jobs with better pay. Adults need higher levels of numeracy to function effectively in their roles as workers, parents, and citizens when one considers the increasingly importance of quantitative and technical aspects of human life in making the world more digitalised. More often than not, numeracy is a key attribute in gaining and retaining employment (Bynner, 2004) with the number of jobs and occupations requiring low-level skills shrinking world-wide and individuals with low level numeracy skills are expected to find it increasingly difficult to compete in the competitively digitalised labour market.

The EU High Level Group of Experts on Literacy (2012) classifies numeracy into three distinct categories: baseline, functional and multiple. Multiple Numeracy- is the ability and willingness to use mathematical modes of thought (logical and spatial thinking) and presentation (formulae, models, graphs, charts) that enable a person to fully function in a modern society, Functional Numeracy -is the ability to apply basic mathematical principles and processes in everyday contexts at home, school and work (as needed for banking, payments, reading timetables, etc.)-, and Baseline Numeracy -is having a sound knowledge of numbers, measures and structures, basic operations, basic mathematical presentations and the ability to use appropriate aids that enable further development.

Ginsburg et al. (2006) through a field-and research-based synthesis of the components required for adults to be numerate, to act numerately, and to acquire numeracy skills, identified three fundamental elements each with different subcomponents that are inherent in proficient numeracy practice. These components form the construct of adult numeracy and each component can be described separately and is different in nature. In actuality they interact, are intertwined, and have little meaning in isolation (Ginsburg et al., 2006).

1. Context -The use and purpose for which an adult takes on a task with mathematical demands (Akinsola \& Awofala, 2008). The context has four subcomponents: Family or Personal, as a parent, household manager, consumer, financial and health-care decision maker, and hobbyist. Workplace, as a worker able to perform tasks on the job and to be prepared to adapt to new employment demands. Further Learning, as one interested in the more formal aspects of mathematics necessary for further education or training. And Community, as a citizen making interpretations of social situations with mathematical aspects such as the environment, crime and politics.

2. Content. The mathematical knowledge that is necessary for the tasks confronted. The content is organised into four strands: Number and Operation Sense, a sense of how numbers and operations work and how they relate to the world situations that they represent. Patterns, Functions and Algebra, an ability to analyze relationships and change among quantities, generalize and represent them in different ways, and develop solution methods based on the properties of numbers, operations and equations. Measurement and Shape, knowledge of the attributes of shapes, how to estimate and/or determine the measure of these attributes directly or indirectly, and how to reason spatially. And Data, Statistics and Probability, the ability to describe populations, deal with uncertainty, assess claims, and make decisions thoughtfully.

3. Cognitive and Affective. The processes that enable an individual to solve problems, and thereby, link the content and context. The cognitive and affective component is divided into five subcomponents: Conceptual Understanding, an integrated and functional grasp of mathematical ideas (Kilpatrick, Swafford \& Findell, 2001) and the two aspects of conceptual understanding -integrated and functional- frame the ability to think and act numerately and effectively (Ginsburg et al., 2006). Adaptive Reasoning, the capacity to think logically about the relationships among concepts and situations (Kilpatrick et al., 
2001). Strategic Competence, the ability to formulate mathematical problems, represent them, and solve them (Kilpatrick et al., 2001) and problem solving represents the heart of numeracy (Ginsburg et al., 2006). Procedural Fluency, the ability to perform calculations efficiently and accurately by using paper and pencil procedures, mental mathematics, estimation techniques, and technological aids (Kilpatrick et al., 2001). And Productive Disposition, the beliefs, attitudes, and emotions that contribute to a person's ability and willingness to engage, use, and persevere in mathematical thinking and learning or in activities with numeracy aspects (Ginsburg et al., 2006). Productive disposition has been identified as a necessary component of mathematical proficiency which should be developed during the course of K-12 mathematics education (Kilpatrick et al., 2001) in both male and female students.

As in advanced mathematics (Akinsola \& Awofala, 2009; Awofala, 2011b; Rogers \& Kaiser, 1995; Sommers, 2008; Stoeger, 2004; Willis, 1989), gender differences permeate numeracy skills (Beilock, Gunderson, Ramirez \& Levine, 2010; Coben et al., 2003; Murray, Clermont \& Binkley, 2005; Parsons \& Bynner, 2005; Satherley \& Lawes, 2009a) and these differences have been ascribed to attitudes, feelings, stereotype threat and the consequences of affective issues as much as to actual cognitive differences (Beaton, Tougas, Rinfret, Huard \& Delisle, 2007; Coben et al., 2003; Hyde \& Mertz, 2009; Mendick, 2005; Rivardo, Rhodes, Camaione \& Legg, 2011; Tomasetto, Alparone \& Cadinu, 2011).

It is evident that the effects of poor numeracy skills seem greater on women than on men (Parsons \& Bynner, 2005; Reder \& Bynner, 2009) with literature suggesting that the gender differences in mathematics performance may be an outcome of teaching approaches that do not relate to preferred learning styles (Awofala, 2011a; Awofala, Balogun \& Olagunju, 2011; Zohar, 2006). More so, literature suggests that gender differences in approaches to mathematics have both biological (Awofala, 2008)-an example being differences in spatial processing (Maloney, Waechter, Risko \& Fugelsang, 2012) and cultural bases (Awofala, 2008)-an example being spatial processing aspects of intelligence tests being culturally defined (Clifford, 2008). In this new millennium and across cultures, the cultural explanation to gender differences in mathematics performance seems to be gaining more prominence in gender literature with biological explanation waning. However, current research is yet to provide unquestionable answers to gender differences in mathematics performance being underlined by biological factors since inconsistently non-similar patterns of gender differences in mathematics ability are found from crosscultural studies (Awofala, 2011b; Kane \& Mertz, 2012).

Meta-analyses of studies on gender difference in mathematics performance across the United States and the United Kingdom (Luckenbill, 1995) revealed that while a very minute gender difference in early mathematics skills was perceptible at elementary school levels, a gender difference in favour of male students appeared in high schools (Hyde \& Mertz, 2009) with the conclusion that differential patterns of course-taking accounted for this difference, with socialisation and discrimination as lesser factors. Although meta-analytic studies on gender difference in mathematics performance is yet to be conducted on the Nigerian sample, international findings regarding gender difference in mathematics performance other than the US and UK showed that females had the same or better performance in mathematics when compared with the males.
This is corroborated by the declining gender gaps in mathematics performance in the European Union (EU) with only $2 \%$ difference on average between low achievers boys (21\%) and low achievers girls (23\%) (EU Skills Panorama, 2012). This finding has had to the argument by Hyde \& Mertz (2009) that gender differences in mathematical performance were due to changeable socio-cultural factors rather than innate biological differences.

Many studies had supported the socio-cultural origin of gender differences in mathematics performance (Ceci \& Williams, 2010, 2011; Lindberg, Hyde, Petersen \& Linn, 2010; York \& Clark, 2007), with ample research indicating that selfconfidence (Carr, Steiner, Kyser \& Biddlecomb, 2008), sexism (Sommers, 2008), and stereotype threat (Steffens \& Jelenec, 2011; Tomasetto et al., 2011) caused or contributed to these disparities. Stereotype threat occurs when the "motivational, affective, psychological, and cognitive processes interact to impair performance in a stereotype-relevant context" (Schmader, Johns \& Forbes, 2008, p. 336) and has been shown to affect numeracy test results through interfering with concentration and co-ordinating information processing.

Bynner and Parsons (2006) found that among individuals born in England and Wales in 1970, males and females had nearly identical levels of literacy skill but there was significantly more gender variation in numeracy, in which skill levels were lower than literacy for both sexes, but especially for women. A 2005 report from the United Kingdom on two longitudinal studies into numeracy and literacy skills using cohorts from 1958 and 1970 found that men had stronger numeracy skills than women (Parsons \& Bynner, 2005). For women, the United Kingdom research reports that "while the impact of low literacy and numeracy skills is substantial, low numeracy has greater negative effect (than for men) even when it is combined with competent literacy” (Parsons \& Bynner, 2005, p. 7). Between 1996 and 2006, inconsistent findings had been found regarding gender differences on the quantitative literacy scores among New Zealand population. The International Adult Literacy Survey (IALS) conducted in 1996 in New Zealand showed a gender difference on the quantitative literacy scores (which covered a subset of numeracy skills rather than the range of numeracy skills covered in the ALLS (Adult Literacy and Life Skills Survey) but the difference (around 5\%) was not statistically significant (Culligan, Sligo, Arnold \& Noble, 2004), whereas the more recent New Zealand ALL survey (2006) showed small, but statistically significantly higher numeracy scores for men than women (Satherley \& Lawes, 2008a, 2008b). The zero-tolerance gender difference in mathematics performance (Fatade, Nneji, Awofala \& Awofala, 2012) was comparable with the much more recent IALS data from Scotland which found no significant gender differences in quantitative literacy scores (St Clair et al., 2010).

In summary, mathematics had for long created social stereotypes and gender inequalities into the educational sector and since its introduction into schools, mathematics had been seen as a male domain or something for boys. This old stereotypic gender differences in cognitive and affective outcomes that formerly subsisted in mathematics were extrapolated to the area of numeracy. Although canonical gender differences in mathematics are declining world-wide and, perhaps, do not have any practical importance for the future, the inconsistent findings regarding gender differences in numeracy have shown the need for more investigations. Unlike the 
developed countries of the world, where researches into adult learner numeracy had reached an appreciable level, there were paucity of studies in Nigeria on adult learner numeracy and numeracy gender related issues. In addition, the not too straightforward findings on gender differences in arithmetic have further provided the needed impetus for the study.

\section{PURPOSE OF THE STUDY}

Therefore, the present study investigated Nigerian adult learner numeracy, the differences in numeracy between men and women, and the relationship between numeracy and performance in arithmetic.

\section{RESEARCH QUESTIONS}

Specifically in this study, the following research questions were addressed:

1. What is the factor structure of the numeracy selfassessment scale?

2. What is the level of perception of numeracy skills among Nigerian adult learners?

3. Is gender a factor in performance in Arithmetic and perception of Numeracy among Nigerian adult learners?

4. What are the composite and relative contributions of dimensions of numeracy (numeracy in everyday life, numeracy in workplace, and numeracy in mathematical tasks) and gender to the explanation of the variance in the adult learners' performance in arithmetic?

\section{METHODOLOGY}

The study made use of quantitative research method within the blueprint of descriptive survey design. The participants in this study were 32 adult learners (16 men and 16 women) from one accredited adult literacy centre in Lagos State, Nigeria. Their age ranged from 18 to 57 years with mean age of 37.8 years. The participants could also be categorised as 3(9.4\%) with age group below 20 years and 29(90.6\%) within the age group 20 years and above. For the purpose of data collection, one instrument tagged Numeracy Self-Assessment Scale (NSAC) adopted from the Human Resources and Skills Development Canada was used to collect primary data relating to adult learners' numeracy skills while secondary data relating to their performance in arithmetic were retrieved from their records in the Adult Learners Literacy Centre. The NSAC consisted of 24 items anchored on a 3-point scale ranging from: Yes -3 , Somewhat -2 , to No-1. The internal consistency reliability coefficient of the NSAC was computed using the Cronbach alpha $(\alpha)$ with a value of 0.87 . The second author personally administered the NSAC to the whole sample and in a regularly schedule class and equally retrieved records pertaining to the adult learners' performance in Arithmetic from the centre for the purpose of this study. Data collected were summarized and analysed using percentages, means, standard deviations, independent samples t-test, principal components factor analysis, Pearson moment correlation, and multiple regression analysis.

\section{RESULTS}

\subsection{Research Questions One: What is the factor structure of the numeracy self-assessment scale?}

Findings from research question 1 shows the responses of the participants to the 24 items of numeracy self-assessment scale were subjected to principal components factor analyses (PCA) to identify their underlying dimensions.

The data screening processes were carried out and showed missing values for three out of 35 participants and these were discarded. Subsequently, further screening showed no concern about normality, linearity, multicollinearity, and singularity. For example, subscale scores were normally distributed with skewness and kurtosis values within acceptable ranges (e.g. skewness ranged from -2.24 to 0.43 , kurtosis ranged from -0.94 to 6.65 ) as Kline (1998) suggested using absolute cut-off values of 3.0 for skewness and 8.0 for kurtosis. The correlation matrix of the 24 items revealed that the correlations when taken overall were statistically significant as indicated by the Bartlett's test of sphericity, $\chi^{2}=2204.08 ; d f=276 ; p<.001$ which tests the null hypothesis that the correlation matrix is an identity matrix. The Kaiser-Meyer-Olkin measure of sampling adequacy (MSA) fell within acceptable range (values of .60 and above) with a value of .871. Each of the variables also exceeded the threshold value (.60) of MSA which ranged from .646 to .882. Finally, most of the partial correlations were small as indicated by the anti-image correlation matrix. These measures all led to the conclusion that the set of 24 items of numeracy self-assessment scale was appropriate for PCA and since no particular number of components was first hypothesized (although not unmindful of $a$ priori criterion of four-factor) the criterion was set to eigenvalues greater than one (Kaiser, 1960; Tabachnick \& Fidell, 2001).

The initial unrotated PCA resulted in a factor model of seven dimensions as indicated by the eigenvalues exceeding unity but the scree plot showed a factor model of three dimensions. However, based on its pattern of factor loadings, this unrotated factor model was theoretically less meaningful and as such was difficult to interpret. Therefore, the analysis proceeded to rotate the factor matrix orthogonally using varimax rotation to achieve a simple and theoretically more meaningful solution. The rotation resulted in a factor model of three dimensions as suggested by the scree plot and eigenvalues exceeding unity.

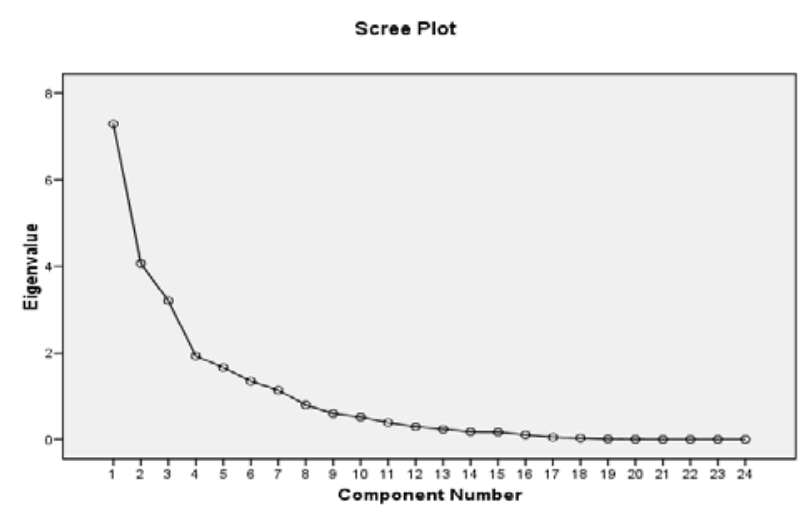

Figure. 1. Cattell scree plot showing number of components and eigenvalues of the correlation matrix 
Table 1. Adult Learners' Perception of Numeracy skills and summary of factor loadings by Principal Components analysis for the or-thogonal three factor model

\begin{tabular}{|c|c|c|c|c|c|c|c|}
\hline \multirow[t]{2}{*}{ A } & \multirow{2}{*}{$\begin{array}{l}\text { Numeracy in everyday life: } \\
\text { Factor } 1 . \text { I can... }\end{array}$} & \multicolumn{3}{|c|}{$\mathbf{N}(\%)$} & \multirow[t]{2}{*}{$M$} & \multirow[t]{2}{*}{$S D$} & \multirow{2}{*}{$\begin{array}{l}\text { Factor Load- } \\
\text { ing }\end{array}$} \\
\hline & & YES & SW & NO & & & \\
\hline 1 & $\begin{array}{l}\text { Perform simple calculations such as addi- } \\
\text { tion and subtraction. }\end{array}$ & 30(93.8) & - & $1(3.1)$ & 2.909 & .426 & .909 \\
\hline 2 & Receive cash payments and make change. & 30(93.8) & & 2(6.3) & 2.818 & .588 & .739 \\
\hline 3 & Calculate the cost of items on a bill. & 31(96.9) & & $1(3.1)$ & 2.909 & .426 & .909 \\
\hline 4 & $\begin{array}{l}\text { Make comparisons (e.g. taller or shorter, } \\
\text { heavier or lighter, greater than or less than). }\end{array}$ & 29(90.6) & & 2(6.3) & 2.818 & .588 & .653 \\
\hline \multirow[t]{3}{*}{5} & $\begin{array}{l}\text { Record time using digital and standard } \\
\text { clocks, watches, or timers. }\end{array}$ & 25(78.1) & & $6(18.8)$ & 2.545 & .858 & .587 \\
\hline & Sub-total & & & & 2.800 & .577 & \\
\hline & $\begin{array}{l}\text { Numeracy in workplace tasks: Factor } 2 \text {. I } \\
\text { can... }\end{array}$ & & & & & & \\
\hline 6 & $\begin{array}{l}\text { Take simple measurements (e.g. length, } \\
\text { weight, temperature). }\end{array}$ & 28(87.5) & & $3(9.4)$ & 2.818 & .588 & .780 \\
\hline 7 & $\begin{array}{l}\text { Estimate quantities (e.g. I need approxi- } \\
\text { mately } 20 \text { copies). }\end{array}$ & 21(65.6) & 2(6.3) & $8(25.0)$ & 2.773 & .612 & .672 \\
\hline 8 & $\begin{array}{l}\text { Estimate measurements (e.g. it is approxi- } \\
\text { mately three feet wide). }\end{array}$ & 26(81.3) & $1(3.1)$ & $4(12.5)$ & 2.455 & .912 & .786 \\
\hline 9 & Create and balance budgets. & $22(68.8)$ & $1(3.1)$ & $7(21.9)$ & 2.546 & .858 & .822 \\
\hline 10 & $\begin{array}{l}\text { Create and monitor schedules (e.g. staffing } \\
\text { or project schedules). }\end{array}$ & 18(56.3) & & 11(34.4) & 1.909 & 1.019 & .822 \\
\hline 11 & $\begin{array}{l}\text { Estimate the time required to complete } \\
\text { specific tasks. }\end{array}$ & $15(46.9)$ & $3(9.4)$ & 11(34.4) & 1.909 & .971 & .802 \\
\hline 12 & $\begin{array}{l}\text { Take precise measurements using special- } \\
\text { ized equipment. }\end{array}$ & $14(43.8)$ & $3(9.4)$ & $12(37.5)$ & 2.046 & .999 & .657 \\
\hline 13 & $\begin{array}{l}\text { Compare similar products with differing } \\
\text { cost structures to determine the best value. }\end{array}$ & $14(43.8)$ & $3(9.4)$ & 11(34.4) & 2.046 & .999 & .598 \\
\hline 14 & $\begin{array}{l}\text { Manage complex budgets (e.g. preparing } \\
\text { financial statements, forecasting materials). }\end{array}$ & $15(46.9)$ & $3(9.4)$ & $10(31.3)$ & 2.091 & .971 & .657 \\
\hline \multirow[t]{3}{*}{15} & $\begin{array}{l}\text { Make accurate estimates when information } \\
\text { is limited. }\end{array}$ & 17(53.1) & $3(9.4)$ & $10(31.3)$ & 2.227 & .922 & .721 \\
\hline & Sub-total & & & & 2.282 & .885 & \\
\hline & $\begin{array}{l}\text { Numeracy in mathematical tasks: Factor } \\
\text { 3. I can... }\end{array}$ & & & & & & \\
\hline 16 & $\begin{array}{l}\text { Perform calculations that require multipli- } \\
\text { cation and/or division. }\end{array}$ & 17(53.1) & $2(6.3)$ & 11(34.4) & 1.636 & .902 & .760 \\
\hline 17 & Calculate percentages. & $16(50.0)$ & $1(3.1)$ & $14(43.8)$ & 2.046 & .999 & .775 \\
\hline 18 & $\begin{array}{l}\text { Calculate the area of common shapes (e.g. } \\
\text { square, triangle, circle). }\end{array}$ & 28(87.5) & $1(3.1)$ & $3(9.4)$ & 2.682 & .716 & .733 \\
\hline 19 & $\begin{array}{l}\text { Perform measurement conversions (e.g. } \\
\text { inches to centimetres, millilitres to litres). }\end{array}$ & 26(81.3) & $1(3.1)$ & $5(15.6)$ & 2.500 & .859 & .833 \\
\hline 20 & Calculate simple averages & $27(84.4)$ & $1(3.1)$ & $4(12.5)$ & 2.591 & .796 & .805 \\
\hline 21 & $\begin{array}{l}\text { Perform calculations that require multiple } \\
\text { steps or operations. }\end{array}$ & $26(81.3)$ & $1(3.1)$ & $5(15.6)$ & 2.500 & .859 & .677 \\
\hline 22 & $\begin{array}{l}\text { Calculate areas and volumes of irregular } \\
\text { shapes. }\end{array}$ & 26(81.3) & $1(3.1)$ & $5(15.6)$ & 2.500 & .859 & .620 \\
\hline 23 & Measure curved and irregular lengths. & $21(65.6)$ & $1(3.1)$ & $9(28.1)$ & 2.227 & .973 & .801 \\
\hline 24 & Analyze and compare statistical data. & $19(59.4)$ & 2(6.3) & $7(21.9)$ & 2.273 & .935 & .704 \\
\hline & Sub-total & & & & 2.328 & .877 & \\
\hline & Total & & & & 2.470 & .780 & \\
\hline
\end{tabular}

In this study, all the communalities for the factor analysis satisfied the minimum requirement of being larger than 0.50 , in fact these ranged from 0.697 to 0.982 . Figure 1 below is the scree plot which graphs the eigenvalue against the component number and is suggestive of a three component model.

Table 1 displayed the factor loadings for the orthogonal threefactor model of numeracy self-assessment scale. All items loaded .587 and above on their primary factor; none of the secondary loadings exceeded .35. Together the three factors accounted for $60.65 \%$ of the total variance. The first factor accounted for $30.37 \%$ of the variance (eigenvalue $=7.29$ ) and consisted of five numeracy in everyday life items. The second factor accounted for $16.93 \%$ of the variance (eigenvalue $=4.06$ ) and consisted of ten numeracy in workplace tasks items. The third factor accounted for $13.34 \%$ of the variance (eigenvalue $=$
3.20) and consisted of nine numeracy in mathematical tasks items. The internal consistency reliabilities for the subscales are: numeracy in everyday life $(\alpha=.72)$, numeracy in workplace tasks $(\alpha=.78)$, and numeracy in mathematical tasks $(\alpha=.83)$, and the internal consistency reliability for the entire scale $(\alpha=$ .87) was considered very high and conceptually meaningful (Curtis \& Singh, 1997). Thus, the three measures represent empirically separable and internally consistent numeracy selfassessment constructs. 


\subsection{Research Questions Two: What is the level of perception of numeracy skills among Nigerian adult learners?}

Table 1 above showed the overall perception of numeracy skills among Nigerian adult learners. Actual numbers and percentages for responses to each statement were shown in the table. The percentages were in parenthesis. Table 1 showed that the adult learners in the present study had average numeracy strength $(M e a n=2.470, S D=0.780)$. In relation to numeracy in everyday life dimension, more than 90 percent of the adult learners said yes to such numeracy skills, as I can perform simple calculations such as addition and subtraction (item 1 ), receive cash payments and make change (item 2), calculate the cost of items on a bill (item 3), make comparisons (e.g. taller or shorter, heavier or lighter, greater than or less than) (item 4) while more than 75 percent of the adult learners said yes to numeracy skill such as I can record time using digital and standard clocks, watches, or timers (item 5). As indicated in Table 1 above, the adult learners had high numeracy strength (Mean=2.800, $S D=0.577$ ) regarding numeracy in everyday life dimension. This should be expected considering their exposure to everyday life activities that involved the application of basic arithmetic operations

In the case of numeracy in workplace tasks dimension (Table 1), more than 80 percent of the adult learners responded yes to such statements as: I can take simple measurements (e.g. length, weight, temperature) (item 6) and estimate measurements (e.g. it is approximately three feet wide) (item 8). More than 50 percent of the respondents said yes to such numeracy skills statements such as I can estimate quantities (e.g. I need approximately 20 copies) (item 7), create and balance budgets (item 9), create and monitor schedules (e.g. staffing or project schedules) (item 10), and make accurate estimates when information is limited (item 15) whereas more than 40 percent of the adult learners responded yes to such numeracy skills statements as, I can estimate the time required to complete specific tasks (item 11), take precise measurements using specialized equipment (item 12), compare similar products with differing cost structures to determine the best value (item 13), and manage complex budgets (e.g. preparing financial statements, forecasting materials) (item 14). Table 1 above, showed that the adult learners had average numeracy strength (Mean $=2.282, \quad S D=0.885)$ regarding numeracy in workplace tasks dimension. Unlike the tasks in everyday life, tasks in workplace are more complex and demand higher skills with some specialised training.

Assessment of numeracy in mathematical tasks dimension as contained in Table 1 above, showed that more than 80 percent of the adult learners responded yes to such numeracy statements as, I can calculate the area of common shapes (e.g. square, triangle, circle) (item 18), perform measurement conversions (e.g. inches to centimetres, millilitres to litres) (item 19), calculate simple averages (item 20), perform calculations that require multiple steps or operations (item 21), and calculate areas and volumes of irregular shapes (item 22) while more than 50 percent of the adult learners responded yes to such statements as, I can perform calculations that require multiplication and/or division (item 16), measure curved and irregular lengths (item 23), and analyze and compare statistical data (item 24). Fifty percent of the adult learners said yes to such statement as, I can calculate percentages (item 17). Table 1 above, showed that the adult learners had average numeracy strength (Mean $=2.328, S D=$ 0.877) regarding numeracy in mathematical tasks dimension. Unlike the tasks in everyday life and workplace, mathematical tasks are much more complex, abstract, and more demanding than tasks in workplace and they require higher-order skills and problem solving.

\subsection{Research Questions Three: Is gender a factor in performance in Arithmetic and perception of Numeracy skills among Nigerian adult learners?}

Table 2 below showed the descriptive statistics of mean and standard deviation and t-test values on perception of numeracy score and arithmetic score by male and female adult learners. With respect to the aggregate numeracy skill score, the adult female learners recorded slightly higher mean score $(M=56.56$, $\mathrm{SD}=7.53)$ than their male counterparts $(\mathrm{M}=56.38, \mathrm{SD}=8.10)$. However, this slight difference in mean score was statistically not significant ( $\mathrm{t} 30=-.068, \mathrm{p}=.946$ ). Table 2 below showed that the adult male learners recorded slightly higher mean score $(M=14.00, S D=1.79)$ in perception of numeracy skills in everyday life than their female counterparts $(M=13.94$, $\mathrm{SD}=2.11$ ) and this difference was statistically not significant ( $\mathrm{t} 30=.090, \mathrm{p}=.929)$. In Table 2 , the adult female learners recorded slightly higher mean score $(M=21.81, S D=5.65)$ in numeracy in workplace tasks than their male counterparts $(M=20.00, \quad S D=5.65)$. The difference was statistically not significant ( $\mathrm{t} 30=-.908, \mathrm{p}=.371)$. With respect to numeracy in mathematical tasks, the adult male learners recorded slightly higher mean score $(M=22.38, S D=5.12)$ than their female counterparts $(\mathrm{M}=20.81, \mathrm{SD}=4.26)$. However, this difference in mean score was statistically not significant $(\mathrm{t} 30=.938, \mathrm{p}=.356)$. Table 2 revealed that adult female learners recorded slightly higher mean score $(M=52.13, S D=10.98)$ in Arithmetic than their male counterparts $(M=51.56, \mathrm{SD}=9.20)$. This difference in mean score was not statistically significant ( $\mathrm{t} 30=-.157, \mathrm{p}=.876)$. Thus, we concluded that gender was not a significant factor in adult learners' performance in arithmetic, perception of numeracy skills, and even at the numeracy skills subscale levels.

Table 2. Independent sample t-test analysis of adult learners’ performance in Arithmetic and perception of numeracy skills according to gender

\begin{tabular}{|c|c|c|c|c|c|c|c|}
\hline & Gender & $\mathbf{N}$ & $M$ & $S D$ & Df & $t$ & $p$ \\
\hline \multirow[t]{2}{*}{ Numeracy score } & Male & 16 & 56.3750 & 8.09835 & 30 & -.068 & .946 \\
\hline & Female & 16 & 56.5625 & 7.52745 & & & \\
\hline \multirow[t]{2}{*}{ Numeracy in everyday life } & Male & 16 & 14.0000 & 1.78885 & 30 & .090 & .929 \\
\hline & Female & 16 & 13.9375 & 2.11246 & & & \\
\hline \multirow[t]{2}{*}{ Numeracy in workplace tasks } & Male & 16 & 20.0000 & 5.64506 & & & \\
\hline & Female & 16 & 21.8125 & 5.64764 & 30 & -.908 & .371 \\
\hline \multirow[t]{2}{*}{ Numeracy in math tasks } & Male & 16 & 22.3750 & 5.12348 & & & \\
\hline & Female & 16 & 20.8125 & 4.26175 & 30 & .938 & .356 \\
\hline \multirow[t]{2}{*}{ Arithmetic score } & Male & 16 & 51.5625 & 9.20122 & & & \\
\hline & Female & 16 & 52.1250 & 10.97801 & 30 & -.157 & .876 \\
\hline
\end{tabular}


Table 3. Correlations Matrix for the Relationship between Numeracy self-assessment Dimensions, gender and adult learners performance in Arithmetic

\begin{tabular}{|c|c|c|c|c|c|c|c|}
\hline & 1 & 2 & 3 & 4 & 5 & 6 & \\
\hline 1. Gender & & 1.00 & .029 & -.016 & .164 & -.169 & .012 \\
\hline 2. Arithmetic & & .029 & 1.00 & -.219 & $.657 * *$ & $.369 *$ & $.652 * *$ \\
\hline 3. Numeracy in everyday life (NEL) & -.016 & -.219 & 1.00 & .077 & -.130 & .228 & \\
\hline 4. Numeracy in workplace tasks (NWT) & .164 & $.657 * *$ & .077 & 1.00 & .044 & $.778 * *$ & \\
\hline 5. Numeracy in mathematical tasks (NMT) & -.169 & $.369 *$ & -.130 & .044 & 1.00 & $.611^{* *}$ & \\
\hline 6. Numeracy Skills & & .012 & $.652 * *$ & .228 & $.778 * *$ & $.611^{* *}$ & 1.00 \\
\hline
\end{tabular}

6. Numeracy Skills

\subsection{Research Questions Four: What are the} composite and relative contributions of dimensions of numeracy (numeracy in everyday life, numeracy in workplace, and numeracy in mathematical tasks) and gender to the explanation of the variance in the adult learners' performance in arithmetic?

The results in Table 3 below showed the relationship among the numeracy skills, numeracy self-assessment subscales, gender and performance in arithmetic. Table 3 showed that there was a significant positive correlation between the adult learner performance in arithmetic and numeracy in workplace tasks (Pearson $r=.657, p<.001$ ) and numeracy in mathematical tasks (Pearson $r=.369, p<.05$ ) while gender did not correlate significantly either with performance in arithmetic or numeracy skills dimensions.

More so, there was a significant positive correlation between adult learners' perception of numeracy skills and their performance in arithmetic (Pearson $r=.652, p<.001$ ). The results in Table 4 below showed that the independent variables (Gender, Numeracy in everyday life (NEL), Numeracy in workplace tasks (NWT), and Numeracy in mathematical tasks (NMT)) jointly contributed a coefficient of multiple regression of .601 and a multiple correlation square of .542 to the prediction of adult learners' performance in arithmetic.

By implication, $60.1 \%$ of the total variance of the dependent variable (performance in arithmetic) was accounted for by the combination of the four independent variables. The results further revealed that the analysis of variance of the multiple regression data produced an $F$-ratio value significant at 0.001 level $\left(F_{(4,27)}=10.157 ; p<.001\right)$.

The results of the relative contributions of the independent variables to the prediction of adult learners' performance in arithmetic was that numeracy in workplace tasks was the potent significant positive contributor to the prediction of adult learners' performance in arithmetic $(\beta=.667, t=5.38, p<.001)$, while numeracy in mathematical tasks dimension of numeracy self-assessment skills made the next significant positive contribution to the prediction of the dependent variable $(\beta=.305$, $t=2.44, p=.022)$. Numeracy in everyday life $(\beta=-.231, t=-$ 1.88, $p=.072)$ and gender $(\beta=-.033, t=-.261, p=.796)$ did not make any significant positive contribution to the prediction of adult learners' performance in arithmetic.

Afterwards, a stepwise regression analysis was used to determine the contribution of each of these variables in predicting performance in arithmetic. A reduced model explaining the predictive capacity of the two variables (numeracy in workplace tasks and numeracy in mathematical tasks) on performance in arithmetic is outlined in Table 5 below. Model 1, which includes only numeracy in workplace tasks scores, is accounted for $43.2 \%$ of the variance in adult learners' performance in arithmetic. The inclusion of numeracy in mathematical tasks into Model 2 resulted in additional 54.8\% of the variance being explained. This means that numeracy in mathematical tasks alone accounted for $11.6 \%$ of the variance in adult learners' performance in arithmetic.

\section{DISCUSSION}

The results of the present study have highlighted five main findings. These findings relate to establishing the factor structure of the numeracy self-assessment scale with adult learners; determining the level of perception of numeracy skills among adult learners; determining whether differences existed between male and female adult learners in perception of numeracy skills and performance in arithmetic; and ascertaining composite and relative contributions of numeracy skills dimensions and gender to the prediction of adult learners' performance in arithmetic.

The results of the present study showed that numeracy skill as measured by numeracy self-assessment scale is a multi-

Table 4. Model Summary, Coefficient and t-Value of Multiple Regression Analysis of Numeracy self-assessment skills Dimensions, gender and the Outcome Measure (performance in Arithmetic)

\begin{tabular}{|c|c|c|c|c|c|}
\hline \multicolumn{6}{|c|}{$\begin{array}{l}\text { Model Summary } \\
\text { Multiple } R=.775 \\
\text { Multiple } R^{2}=.601 \\
\text { Multiple } R^{2} \text { (Adjusted) }=.542 \\
\text { Standard Error Estimate }=6.748 \\
F=10.157, p<.001\end{array}$} \\
\hline \multirow[t]{2}{*}{ Model } & \multicolumn{2}{|c|}{ Unstandardized Coefficients } & \multirow{2}{*}{$\begin{array}{c}\text { Standardized Coeff. } \\
\text { Beta } \\
\end{array}$} & \multirow[t]{2}{*}{$\mathbf{t}$} & \multirow[t]{2}{*}{ Sig } \\
\hline & B & Std. Error & & & \\
\hline (Constant) & 30.87 & 12.49 & & 2.47 & .020 \\
\hline Gender & -.64 & 2.46 & -.033 & -2.61 & .796 \\
\hline NEL & -1.20 & .64 & -.231 & -1.88 & .072 \\
\hline NWT & 1.18 & .22 & .667 & 5.38 & .000 \\
\hline NMT & .646 & .27 & .305 & 2.44 & .022 \\
\hline
\end{tabular}


Table 5. Summary of stepwise regression results with numeracy in workplace tasks and numeracy in mathematical tasks entered for final model explaining performance in arithmetic

\begin{tabular}{|c|c|c|c|c|c|c|c|c|c|c|}
\hline Model & Independ. Variables & B & SEB & $\beta$ & $t$ & $p$ & $\mathbf{R}$ & $\mathbf{R}^{2}$ & $\mathbf{F}$ & $p$ \\
\hline \multirow[t]{2}{*}{1} & Constant & 27.52 & 5.269 & - & 5.223 & .000 & .657 & 432 & 22.817 & .000 \\
\hline & NWT & 1.164 & .244 & .657 & 4.777 & .000 & & & & \\
\hline \multirow[t]{3}{*}{2} & Constante & 12.439 & 7.30 & - & 1.705 & .099 & .741 & .548 & 17.607 & .000 \\
\hline & NWT & 1.137 & .221 & .642 & 5.143 & .000 & & & & \\
\hline & NMT & .724 & .265 & .341 & 2.734 & .011 & & & & \\
\hline
\end{tabular}

dimensional construct. The exploratory factor analysis using the principal components analysis showed a three factor structure underlying the scale. The three interpretable factor structures are subsequently labelled: Numeracy in everyday life (with 5 items), Numeracy in workplace tasks (with 10 items), and Numeracy in mathematical tasks (with 9 items) and each subscale had adequate internal consistency reliability. The adult learners in the present study had average numeracy strength (Mean $=2.470$, $S D=0.780$ ). This finding was in contrast with previous findings (Smit \& Mji, 2012) which showed low level of numeracy among adult chrome mine workers in South Africa. In addition, findings from the United States had revealed that level of numeracy among vulnerable groups in the society such as the elderly, women and those with low educational attainment was very low (Lusardi, 2012). This was contrary to the findings from Sweden and Poland which showed that level of numeracy among their populations was very high (Johnston, 2002).

The findings relating to gender differences in perception of numeracy skills and performance in arithmetic showed that in the present study male and female adult learners recorded comparable mean scores in performance in arithmetic and on each of the numeracy skills dimensions. Thus, gender differences in numeracy skills and performance in arithmetic as shown in this study was not significant. These findings were in agreement with previous study findings (Arigbabu \& Mji, 2004; Fatade, Nneji, Awofala \& Awofala, 2012) in advanced mathematics among preservice mathematics teachers but ran contrary to other previous findings (Beilock et al., 2010; Coben et al., 2003; Murray et al., 2005; Parsons \& Bynner, 2005; Satherley \& Lawes, 2008a, 2008b; Satherley \& Lawes, 2009a, 2009b, 2009c) which revealed the existence of significant gender differences in numeracy skills. The implication of the present study findings regarding gender is that gender differences in numeracy skills and performance in arithmetic are no longer important.

The results displayed in Table 4 showed that $60.1 \%$ of the variance in adult learners' performance in arithmetic was accounted for by the four predictor variables (gender, numeracy in everyday life, numeracy in workplace tasks, and numeracy in mathematical tasks) taken together. The relationship between performance in arithmetic and the predictor variables taken together were high as shown by the coefficient of multiple correlation $(R=.775)$. Thus, the predictor variables investigated when taken together predicted to some extent arithmetic performance among adult learners involved in the study. The observed $\left(F_{(4,27)}=10.157 ; p<.001\right)$ is a reliable evidence that the combination of the dimensions of numeracy skills in the prediction of adult learners' performance in arithmetic from all indications did not occur by chance with $39.9 \%$ of the variance in arithmetic performance not unexplained by the current data. Thus, there might be other independent variables which may require further investigations about their contribution to the prediction of adult learners' performance in arithmetic and the degree of prediction jointly made by the four independent variables of this study could be substantive enough to assert that adult learners' performance in arithmetic is predictable by a combination of the dimensions of numeracy skills and gender. Thus, the strength of the predictive power of the combined independent variables (numeracy in everyday life, numeracy in workplace, numeracy in mathematical tasks, and gender) on the outcome variable was strong and significant to show the linear relationship between the four predictor variables and the total variance in adult learners' performance in arithmetic. According to the standardized coefficients the regression model is as follows: Performance in Arithmetic predicted $=30.875-0.033$ gender -0.231 numeracy in everyday life +0.667 numeracy in workplace tasks +0.305 numeracy in mathematical tasks.

On the relative contribution of each of the independent variables to the explanation of variance in adult learners' performance in arithmetic, the present study revealed that only two (numeracy in workplace tasks and numeracy in mathematical tasks) out of the four independent variables made statistically significant contribution to the variance in adult learners' performance in arithmetic. Numeracy in workplace tasks was the best predictor of performance in arithmetic and accounted for $43.2 \%$ of the variance in adult learners' performance in arithmetic. This was followed by numeracy in mathematical tasks which alone accounted for $11.6 \%$ of the variance in adult learners' performance in arithmetic. Gender and numeracy in everyday life did not contribute meaningfully to the prediction of adult learners' performance in arithmetic.

\section{LIMITATIONS OF THE STUDY}

It is worthy of note that the findings that emerged in this study may not be generalised to all Nigerian adult learners as the sample was not necessarily representative of all adult learners. The small sample size $(n=32)$ notwithstanding, it is noted that perception of numeracy scores obtained among this group of adult learners may have been influenced by their literacy ability and anxiety regarding numbers. Some adult learners who were part of the assessments may not have properly understood some of the numeracy statements which could also invoke anxiety in them. The present study investigated adult learners' numeracy using individual self-assessment scale which is often criticised for promoting measurement error. People may over or understate their level of literacy and numeracy skills in order to conform to societal standard. It is recommended that future studies in Nigeria should investigate adult learners' numeracy skills using more robust and psychometrically sound instruments such as the Adult Literacy and Life Skills Survey (ALLS) and the International Adult Literacy Survey (IALS). However, we are of the opinion that the present study is vital in exposing the level of numeracy perception among adult learners as the study 
findings could serve as a baseline for conducting future studies in adult numeracy in Nigeria.

\section{REFERENCES}

Akinsola, M. K., \& Awofala, A. O. A. (2009). Effects of personalization of instruction on students' achievement and self-efficacy in Mathematics word problems. International Journal of Mathematical Education in Science and Technology, 40(3), 389-404. doi: 10.1080/00207390802643169

Akinsola, M. K., \& Awofala, A. O. A. (2008). Effects of problem context and reasoning complexity on Mathematics problem solving achievement and transfer of Secondary School students. European Journal of Scientific Research, 20(3), 641-651.

Arigbabu, A. A., \& Mji, A. (2004). Is gender a factor in Mathematics Performance among Nigerian pre-service teachers? Sex Roles, 51(11), 749-53. doi: 10.1007/s11199-004-0724-z

Awofala, A. O. A. (2008): Women and the learning of Mathematics. African Journal of Historical Sciences in Education, 2(1), 195-213.

Awofala, A. O. A. (2011a). Effect of concept mapping strategy on students' achievement in Junior Secondary School Mathematics. International Journal of Mathematics Trends and Technology, 2(3), 11-16.

Awofala, A. O. A. (2011b). Is gender a factor in Mathematics performance among Nigerian Senior Secondary School Students with varying School Organization and Location? International Journal of Mathematics Trends and Technology, 2(3), 17-21.

Awofala, A. O. A., Balogun, T. A., \& Olagunju M. A. (2011). Effects of three modes of personalisation on students' achievement in mathematical word problems in Nigeria. International Journal of Mathematics Teaching and Learning, 1-25. Retrieved from http://www.cimt.plymouth.ac.uk/journal/awofala.pdf

Baker, D. (1998). Numeracy as social practice. Literacy \& Numeracy Studies, 8(1), 37-50.

Barton, D., Hamilton, M., \& Ivanic, R. (2000). Situated literacies: Reading and writing in context. London, UK: Routledge.

Beaton, A., Tougas, F., Rinfret, N., Huard, N., \& Delisle, M. (2007). Strength in numbers? Women and mathematics. European Journal of Psychology of Education, 22(3), 291-306. doi: 10.1007/BF03173427

Beilock, S., Gunderson, E., Ramirez, G., \& Levine, S. (2010). Female teachers' math anxiety affects girls' math achievement. Proceedings of the National Academy of Sciences, 107(5), 1860-1863. doi: 10.1073/pnas.0910967107

Benseman, J. (2008). Foundation learning in New Zealand: An overview. In J. Benseman \& A. Sutton (Eds.), Facing the Challenge: Foundation learning for adults in Aotearoa New Zealand. Wellington, New Zealand: Dunmore.

Benseman, J., \& Sutton, A. (2007). A synthesis of foundation learning evaluation and research in New Zealand since 2003. Retrieved from http://www.dol.govt.nz/PDFs/learning-and-evaluation-july-2007.pdf

Benseman, J., \& Sutton, A. (2011). Understanding the needs of adult literacy, language and numeracy learners with very low skills: Insights from the research. Journal of Adult Learning in Aotearoa New Zealand, 39(1), 7-18.

Benseman, J., \& Sutton, A. (Eds.). (2008). Facing the challenge: Foundation learning for adults in Aotearoa New Zealand. Wellington, New Zealand: Dunmore.

Bernstein, B. (1999). Vertical and horizontal discourse: An essay. British Journal of Sociology of Education, 20(2), 157-173. doi: 10.1080/01425699995380

Best, J. (2008). Birds-dead and deadly: Why numeracy needs to address social construction. Numeracy, 1(1). doi: 10.5038/1936-4660.1.1.6

Bynner, J., \& Parsons, S. (1997a). It doesn't get any better: The impact of poor basic skills on the lives of 37 year olds. London: The Basic Skills Agency.

Bynner, J., \& Parsons, S. (1997b) Does Numeracy Matter? Evidence from the National Child Development Study on the impact of poor numeracy on adult life. London: Basic Skills Agency.

Bynner, J., \& Parsons, S. (1998). Use it or lose it: the impact of time out of work on literacy and numeracy skills. London: Basic: Skills Agency.

Bynner, J. (2004). Literacy, numeracy and employability: Evidence from the British birth cohort studies. Literacy and Numeracy Studies, 13(1), 31-48.

Bynner, J., \& Parsons, S. (2006). New light on literacy and numeracy: Full report. London, UK: NRDC.

Carr, M., Steiner, H., Kyser, B., \& Biddlecomb, B. (2008). A comparison of predictors of early emerging gender differences in mathematics competency. Learning and Individual Differences, 18(1), 61-75. doi: 10.1016/j.lindif.2007.04.005

Ceci, S., \& Williams, W. (2010). Sex differences in math-intensive fields. Current Directions in Psychological Science, 19(5), 275-279. doi: $10.1177 / 0963721410383241$

Ceci, S., \& Williams, W. (2011). Understanding current causes of women's underrepresentation in science. Proceedings of the National Academy of Sciences, 108(8), 3157-3162. doi: 10.1073/pnas.1014871108
Clifford, E. (2008). Visual-spatial processing and mathematics achievement: The predictive ability of the visual-spatial measures of the Stanford-Binet intelligence scales, Fifth Edition and the Wechsler Intelligence Scale for ChildrenFourth Edition. University of South Dakota, Vermillion SD.

Coben, D., \& Chanda, N. (2000). Teaching "not less than maths, but more": an overview of recent developments in adult numeracy teacher development in england - with a sidelong glance at Australia. In D. Coben, J. O'Donoghue, \& G. FitzSimons (Eds.), Perspectives on adults learning mathematics: research and practice. Kluwer Academic Publishers, London.

Coben, D. (2000). Numeracy, mathematics, and adult learning. In I. Gal (Ed.), Adult numeracy: Theory, research, practice. Cresskill, NJ: Hampton Press Inc.

Coben, D., Colwell, D., Macrae, S., Brown, M., Boaler, J., \& Rhodes, V. (2003). Adult numeracy: Review of research and related literature. London, England: NRDC.

Cockcroft, W. H. (1982). Mathematics counts: report of the Committee of Inquiry into the Teaching of Mathematics in Schools, H. M. S. O., London.

Cohen, L., L. Manion, \& K. Morrison. 2007. Research methods in education. London: Routledge Falmer.

Condelli, L., Safford-Ramus, K., Sherman, R., Coben, D., Gal, I., \& HectorMason, A. (2006). A Review of the Literature in Adult Numeracy: Research and Conceptual Issues. Prepared by American Institutes for Research (AIR), 1000 Thomas Jefferson Street, NW| Washington, DC 20007-3835.

Crowther Report. (1959). Report of the Central Advisory Council of Education (England) (Vol. 1: pp. 15-18). London: HMSO.

Culligan, N., Sligo, F., Arnold, G., \& Noble, A. (2004). Analysis of New Zealand data from the International Adult Literacy Survey: Demographic predictors of low literacy proficiency (Final report).

Curtis, W. J., \& Singh, N. N. (1997). The psychometric characteristics of the Henderson environmental learning process scale. Educational and Psychological Measurement, 57, 280-291. doi: 10.1177/0013164497057002007 Retrieved from

http://www.massey.ac.nz/massey/fms/Colleges/College\%20of\%20Business/Co mmunica-

tion\%20and\%20Journalism/Literacy/Publications/Analysis\%20of\%20New\%20 Zealand\%20Data.pdf

De Lange, J. (2003). Mathematics for literacy. In B. L. Madison and L. A. Steen (Eds.), Quantitative literacy: Why numeracy matters for schools and colleges (pp. 75-89). Proceedings of the National Forum on Quantitative Literacy held at the National Academy of Sciences in Washington, D.C. on December 1-2, 2001. Princeton NJ: National Council on Education and the Disciplines.

EU High Level Group of Experts on Literacy (2012) Final Report. Retrieved from http://ec.europa.eu/education/literacy/what-eu/high-levelgroup/documents/literacy-final-report_en.pdf

EU Skills Panorama (2012). Literacy and Numeracy Analytical Highlight. Retrieved from http://euskillspanorama.ec.europa.eu/docs/AnalyticalHighlights/LiteracyNumer acy_en.pdf

Evans, J. (2000). Adults' mathematical thinking and emotions: A study of numerate practices. London, UK: Routledge/Falmer.

Fatade, A. O., Nneji, L. M., Awofala, A. O. A., \& Awofala, A. A. (2012). Mode of Entry and Gender as Determinants of Nigerian Pre-service Teachers' Performance in Degree Mathematics and Science Courses. International Journal of Mathematics Trends and Technology, 3(3), 103-109.

Gal, I., van Groenestijn, M., Manly, M., Schmitt, M. J., \& Tout, D. (2005). Adult numeracy and its assessment in the ALL Survey: A conceptual framework and pilot results. In T. S. Murray, Y. Clermont, \& M. Binkley (Eds.), Measuring adult literacy and life skills: New frameworks for assessment. Ottawa, Canada: Statistics Canada.

Ginsburg, L., Manly, M., \& Schmitt, M. J. (2006). The components of numeracy [NCSALL Occasional Paper]. Cambridge, MA: National Center for Study of Adult Literacy and Learning. Retrieved from http://www.ncsall.net/fileadmin/resources/research/op_numeracy.pdf

Goyen, J. (1977). Adult illiteracy in Sydney. Canberra: Australian Association of Adult Education.

Hyde, J., \& Mertz, J. (2009). Gender, culture, and mathematics performance. Proceedings of the National Academy of Sciences, 106(22), 8801-8807. doi: 10.1073/pnas.0901265106

Johnston, B. (1994). Critical numeracy?, Fine Print, 16(4), 32-35.

Johnston, B. (2002). Numeracy in the making: twenty years of Australian adult numeracy. An investigation by the New South Wales Centre Adult Literacy and Numeracy Australian Research Consortium (ALNARC) University of Technology, Sydney ALNARC National Research Program 2001-2002.

Kaiser, H. F. (1960). The application of electronic computers to factor analysis. Educational and Psychological Measurement, 20, 141-151. doi: $10.1177 / 001316446002000116$ 
Kane, J., \& Mertz, J. (2012). Debunking myths about gender and mathematics performance. Notices of the AMS, 59(1), 10-21. doi: 10.1090/noti790

Kilpatrick, J., Swafford, J., \& Findell, B. (Eds.) (2001). Adding it up: Helping children learn mathematics. Washington, DC: National Academy Press.

Kline, R. (1998). Principles and practice of structural equation modeling. New York: Guilford Press.

Lindberg, S., Hyde, J., Petersen, J., \& Linn, M. (2010). New trends in gender and mathematics performance: A meta-analysis. Psychological Bulletin, 136(6), 1123-1135. doi: $10.1037 / \mathrm{a} 0021276$

Lindenskov, L., \& Wedege, T. (2001). Numeracy as an analytical tool in adult education and research [Publication No. 31]. Centre for Research in Learning Mathematics, Roskilde University.

Lowden, K., Pownwy, J., Gardner, J., \& Mark, R. (1995). Adult literacy and numeracy: meeting the needs of participants (SCRE Research Report). Glasgow: Scottish Council for Research in Education (SCRE).

Luckenbill, L. M. (1995) "Biological Superiority in Math: Calvin or Susie? Spotlight: Gender Differences”. Montessori Life 7 (4) 28-32

Lusardi, A. (2012). Numeracy, financial literacy, and financial decision-making. National Bureau of Economic Research (NBER), Working Paper 17821. Retrieved March 18, 2010 from http://www.nber.org/papers/w17821

Maguire, T., \& O’Donoghue, J. (2002). A grounded approach to practitioner training in Ireland: Some findings from a national survey of practitioners in Adult Basic Education. In L. Ø.Johansen \& T. Wedege (Eds.), Numeracy for empowerment and democracy? Proceedings of the 8th International Conference of Adult Learning Mathematics - A Research Forum (ALM8) (pp. 120132). Roskilde, Denmark,Roskilde University, Centre for Research in Learning Mathematics. Hent, UK: Avanti Books.

Maloney, E. A., Waechter, S., Risko, E. F., \& Fugelsang, J. A. (2012). Reducing the sex difference in math anxiety: The role of spatial processing ability. Learning and Individual Differences, 22(3), 380-384. doi: 10.1016/j.lindif.2012.01.001

Mendick, H. (2005). A beautiful myth? The gendering of being/doing "good at maths." Gender and Education, 17(2), 203-219. doi: 10.1080/0954025042000301465

Murray, T. S., Clermont, Y., \& Binkley, M. (Eds.). (2005). International adult literacy survey: Measuring adult literacy and life skills: New frameworks for assessment. Ottawa, Canada: Statistics Canada.

OECD, \& Statistics Canada. (2000). Literacy in the information age: Final report of the International Adult Literacy Survey. Paris, France: OECD.

OECD (2000). Literacy in the information age: final report of the International Adult Literacy Survey. Paris: Organisation for Economic Cooperation and Development.

Orrill, R. (2001). Mathematics, numeracy, and democracy. In L. A. Steen (Ed.), Mathematics and democracy (pp xiii-xix). Princenton, NJ: Woodrow Wilson National Fellowship Foundation.

Parsons, S., \& Bynner, J. (2005). Does numeracy matter more? London, UK: NRDC.

Parsons, S., \& Bynner, J. (2007). Illuminating disadvantage: Profiling the experiences of adults with entry level literacy or numeracy over the lifecourse. London, England: NRDC.

Paulos, J. A. (1989). Innumeracy: Mathematical illiteracy and its consequences. New York: Hill \& Wang.

Prinsloo, M. (1999). Literacy in South Africa. In D. A. Wagner, R. Venezky, \& B V. Street (Eds.), Literacy: An international handbook (pp. 418-423). Boulder, CO: Westview Press.

Rassool, N. (1999). Literacy for sustainable development in the age of information. Clevedon: Multilingual Matters Ltd.

Reder, S., \& Bynner, J. (2009). Tracking adult literacy and numeracy skills: Findings from longitudinal research. Routledge Research in Education. Oxford, UK: Routledge.

Rivardo, M., Rhodes, M., Camaione, T., \& Legg, J. (2011). Stereotype threat leads to reduction in number of math problems women attempt. North American Journal of Psychology, 13(1), 5-16.

Rogers, P., \& Kaiser, G. (1995). Equity in Mathematics Education: Influences of Feminism and Culture. London: The Falmer Press.

Satherley, P., \& Lawes, E. (2008a). The Adult Literacy and Life Skills (ALL) Survey: Gender, ethnicity and literacy. Wellington: Ministry of Education.

Satherley, P., \& Lawes, E. (2008b). The Adult Literacy and Life Skills (ALL) Survey: Age and literacy. Wellington, New Zealand: Ministry of Education.

Satherley, P., \& Lawes, E. (2009a). Literacy and life skills for Maori adults. Wellington, New Zealand: Ministry of Education.

Satherley, P., \& Lawes, E. (2009b). The Adult Literacy and Life Skills (ALL) Survey: Numeracy skills and education in New Zealand and Australia. Wellington, New Zealand: Ministry of Education.

Satherley, P., \& Lawes, E. (2009c). Literacy and life skills for Maori adults: Further investigation. Wellington, New Zealand: Ministry of Education.
Schmader, T., Johns, M., \& Forbes, C. (2008). An integrated process model of stereotype threat effects on performance. Psychological Review, 115(2), 336356. doi: 10.1037/0033-295X.115.2.336

Smit, A. C., \& Mji, A. (2012). Assessment of Numeracy Levels of Mine Workers in South African Chrome Mines. Numeracy, 5(2), 1-10. doi: 10.5038/19364660.5.2.4

Retrieved from http://scholarcommons.usf.edu/numeracy/vol5/iss2/art4.

Sommers, C. (2008). Foolishly seeking gender equity in math and science. USA Today Magazine, 137(2760), 58-62.

St Clair, R., Tett, L., \& Maclachlan, K. (2010). Scottish survey of adult literacies 2009: Report of findings. Edinburgh, Scotland: Scottish Government Social Research.

Retrieved from http://www.scotland.gov.uk/Publications/2010/07/22091814/0

Steen, L. A., \& Madison, B. L. (2011). Reflections on the tenth Anniversary of Mathematics and Democracy. Numeracy, 4(1). doi: 10.5038/1936-4660.4.1.1

Steen, L. A. (1991). Numeracy. In S. R. Graubard (Ed.), Literacy: An overview by fourteen experts (pp. 211-231). New York: Hill and Wang.

Steen, L. A. (2001). Embracing numeracy. In L. A. Steen (Ed.), Mathematics and democracy: The case for quantitative literacy (pp.107-116). Washington, DC: National Council on Education and the Disciplines.

Steffens, M., \& Jelenec, P. (2011). Separating implicit gender stereotypes regarding math and language: Implicit ability stereotypes are self-serving for boys and men, but not for girls and women. Sex Roles, 64, 324-335. doi: 10.1007/s11199-010-9924-x

Stoeger, H. (2004, June). Editorial: Gifted females in mathematics, the natural sciences and technology. High Ability Studies, pp. 3-5.

Tabachnick, B.G., \& Fidell, L.S. (2001). Using multivariate statistics [4th edition] Boston, MA: Allyn \& Bacon.

Tett, L., Hall, S., Maclachlan, K., Thorpe, G., Edwards, V., \& Garside, L. (2006). Evaluation of the Scottish adult literacy and numeracy (ALN) strategy (final report). Edinburgh: Scottish Executive.

Tomasetto, C., Alparone, F. R., \& Cadinu, M. (2011). Girls’ math performance under stereotype threat: The moderating role of mothers' gender stereotypes. Developmental Psychology, 47(4), 943-949. doi: 10.1037/a0024047

Wedege, T. (2003). Researching adults mathematics in work. In J. Maasz \& W. Schloeglmann (Eds.), Learning mathematics to live and work in our world. Strobl, Austria: Rudolf Trauner.

Wickert, R. (1989). No single measure. A survey of Australian adult literacy. Sydney: Institute of Technical and Adult Teacher Education.

Willis, S. (1989). "Real girls don't do maths": Gender and the construction of privilege. Geelong, Australia: Deakin University Press.

Zohar, A. (2006). Connected knowledge in science and mathematics education. International Journal of Science Education, 28(13), 1579-1599. doi: $10.1080 / 09500690500439199$ 